\title{
Apparent digestibility of simplified and semi-simplified diets, with and without addition of enzymes, and nutritional value of fibrous sources for rabbits $^{1}$
}

\author{
Luiz Carlos Machado², Walter Motta Ferreira ${ }^{3}$, Cláudio Scapinello ${ }^{4}$ \\ ${ }^{1}$ Apoio financeiro: Conselho Nacional de Desenvolvimento Científico e Tecnológico - CNPq e Fundação de Amparo à Pesquisa do Estado \\ de Minas Gerais - FAPEMIG. \\ 2 Departamento de Zootecnia - IFMG - Brasil. \\ ${ }^{3}$ Departamento de Zootecnia - EV-UFMG - Brasil. \\ ${ }^{4}$ Departamento de Zootecnia - UEM - Brasil.
}

ABSTRACT - The objectives of this study were to evaluate the digestibility of the nutrients of simplified and semisimplified diets, with and without inclusion of exogenous enzymes and to determine the nutritional value of the fibrous sources. The tested feedstuffs were: alfalfa hay, hay from the upper third of the cassava foliage and cassava leaf meal, using a completely randomized design with 11 diets and 8 repetitions. The treatments were constituted of 1 reference diet, 2 simplified diets and 8 semi-simplified diets (4 enzymatic inclusion). The enzymes used were carbohydrases (alpha-galactosidase, galactomanose, xylanase and beta glucanase) and phytase. It was observed that the digestibility of the nutrients of the diets was influenced by the type of feed studied. Semi-simplified diets presented coefficients inferior to the reference diet and superior to the simplified diets. Exogenous enzymes promoted improvements in the digestibility of the dry matter (DM), organic matter, crude protein and gross energy. It was also observed that great part of the crude protein of the cassava leaf meal complexed, which depreciated the digestibility of diets with high inclusion of this ingredient. The nutritional value of fibrous sources was $1822.7 \mathrm{kcal}$ digestible energy - DE/kgDM and 122,6 g digestible protein - DP/kg DM, for the hay from the upper third of the cassava foliage; $2232.5 \mathrm{kcalDE} / \mathrm{kgDM}$ and $155.4 \mathrm{gDP} / \mathrm{kgDM}$ for alfalfa hay and $1888.9 \mathrm{kcalDE} / \mathrm{kgDM}$ and $73.6 \mathrm{gDP} / \mathrm{kgDM}$ for the cassava leaf meal. With the exception of diets with elevated inclusion of cassava leaf meal, the semi-simplified diets presented satisfactory coefficients of digestibility improved by the enzymatic inclusion.

Key Words: digestible energy, exogenous enzymes, rabbit production

\section{Introduction}

The study of the digestive efficiency of feedstuffs begins with the quantification of nutritional principles, followed by the determination of digestibility and animal performance coefficients (Santos et al., 2004). As quoted by Cheek et al. (1986) and Gidenne (2000) the rabbit has a low utilization of the fiber fraction due to the rapid passage of feed through the gastrointestinal tract. Through the caecotrophic activity, the digestibility of nutrients, especially protein, is incremented (Carabaño et al., 1988; Carabaño \& Piquer, 1998; Machado et al., 2007; Faria et al., 2008).

Simplified and semi-simplified diets are a new technology which associates economy, provided by the high inclusion of a fibrous ingredient (Machado et al., 2007). Alfalfa is a fiber source generally used in rabbit diets. In Brazil, alfalfa hay is extremely expensive. The aerial part of the cassava is a potential substitute for alfalfa hay. As observed by Flores (1998) the aerial part of the cassava presents high levels of phytic acid, which complexes phosphorus to the plants and reduces the digestibility of the nutritional principles (Bedford, 2000; Nagashiro, 2007). Besides this antinutritional factor, cassava presents high levels of fiber carbohydrates, which can increase the passage rate and protect the cellular function from enzymatic attack.

Exogenous enzymes increase digestibility, especially through the reduction of the antinutritional potential of the phytic acid and the fiber carbohydrates, leading to higher usage of the nutritional principles (Bedford, 2000; Dari, 2004; Nagashiro, 2007).

Considering studies with rabbits, the comprehension of the use of additives and their relation with digestive efficiency is still in course. The objective of this study was to evaluate the apparent digestibility of the simplified and semi-simplified diets, with and without the inclusion of carbohydrases (alpha-galactosidase, galactomanose, xylanase and beta-glucanase) and phytase, and the nutritional values of the fiber sources for growing rabbits. 


\section{Material and Methods}

The experiment was conducted in the Laboratory of Animal Metabolism, located at the Department of Animal Science of the Veterinary School of UFMG from the 15th to the 25th of December 2009. The mean temperature, during the four days of collection was $23,6{ }^{\circ} \mathrm{C}$. Metabolic cages with dimensions $0.30 \times 0.60 \mathrm{~m}$, with feces collection tray (which allows urine separation), semi-automatic feeders and water supply were used.

The feedstuffs evaluated were alfalfa hay (Medicago sativa); hay from the upper third of the cassava foliage (Manihot sculenta, Crantz), Gravetinho variety, harvested at 12 months; and the cassava leaf meal, Jacaré variety, harvested at 4 months, obtained from the processing of the aerial part dried and ground in a tea processing machine; the finest granulometry was used as described by Ferreira et al. (2011) (Table 1).

The basal diet was formulated to meet the requirements proposed by De Blas \& Mateos (1998), which are: digestible energy, 2,500 kcal/kg; crude protein, 145.0 to $162.0 \mathrm{~g} / \mathrm{kg}$; digestible protein, 102.0 to $113.0 \mathrm{~g} / \mathrm{kg}$; calcium, $6.0 \mathrm{~g} / \mathrm{kg}$; total P, $4.0 \mathrm{~g} / \mathrm{kg}$; lysine, $7.5 \mathrm{~g} / \mathrm{kg}$; methionine + cystine, $5.4 \mathrm{~g} / \mathrm{kg}$; threonine, $6.4 \mathrm{~g} / \mathrm{kg}$; tryptophan, $1.5 \mathrm{~g} / \mathrm{kg}$; arginine, $8.1 \mathrm{~g} / \mathrm{kg}$; and acid detergent fiber, 160.0 to $185.0 \mathrm{~g} / \mathrm{kg}$ (Table 2). An exact adjustment for calcium and acid detergent fiber could not be met, because the fiber sources are rich in these nutritional aspects.
As for protein, the balance is prioritized in the form of digestive protein, since the forage sources are rich in protein by moderate digestibility. During formulation, all diets had levels of lysine, methionine + cystine, threonine, tryptophan and arginine balanced in the form of total amino acids. Oil was added to increase the energy density of the diet, and because of the positive contribution to the digestibility of other nutrients (Fernandez-Carmona et al., 1998; Bertechini, 2006); dried molasses were used to improve the quality and palatability of the pellet, and bentonite to improve its quality. At least $50 \mathrm{~g} / \mathrm{kg}$ of source of starch and small amounts of soybean meal were added to the semisimplified diets, to improve the digestive process. When it was not possible to adjust the content of digestible energy, a minimum of $2200 \mathrm{kcal} / \mathrm{kg}$ of dry matter was sought, as proposed by De Blas et al. (2002) and Ferreira \& Pereira (2003), with a minimum adjustment of intake as a function of energy density, in agreement with the chemiostatic regulatory mechanism, in which the increased concentration of some substances at certain points, act in the satiety center by inhibiting the feed intake.

The treatments consisted of 11 diets, as follows: reference diet; simplified diet based on cassava leaf meal and alfalfa hay; semi-simplified diet based on hay from the upper third of the cassava foliage; semi-simplified diet based on alfalfa hay; semi-simplified diet based on cassava leaf meal; semi-simplified diet based of the mix composed of cassava leaf meal and alfalfa hay; semi-simplified diet based

Table 1 - Chemical composition of the fiber ingredients used in the experimental diets

Alfalfa hay Cassava leaf meal Hay from the upper third of cassava foliage

Composition

Dry matter (g/kg NM)

Crude protein $(\mathrm{g} / \mathrm{kg} \mathrm{NM})$

Neutral detergent fiber ( $\mathrm{g} / \mathrm{kg} \mathrm{NM})$

Acid detergent fiber $(\mathrm{g} / \mathrm{kg} \mathrm{NM})$

Hemicelluloses (g/kg NM)

Acid detergent lignin ( $\mathrm{g} / \mathrm{kg} \mathrm{NM}$ )

Acid detergent insoluble nitrogen (g/kg acid detergent fiber)

Lignified protein $(\mathrm{g} / \mathrm{kg} \mathrm{CP})^{1}$

Gross energy (kcal/kg NM)

Composition obtained in the literature ${ }^{2}$

Calcium (g/kg NM)

Total phosphorus (g/kg NM)

Lysine $(\mathrm{g} / \mathrm{kg} \mathrm{NM})$

Methionine + cystine (g/kg NM)

Threonine (g/kg NM)

Tryptophan (g/kg NM)

Arginine (g/kg NM)

Digestible protein (g/kg NM)
Digestible energy $(\mathrm{kcal} / \mathrm{kg} \mathrm{NM})^{3}$

$\begin{array}{ccc}891.5 & 936.1 & 906.5 \\ 171.5 & 195.4 & 179.6 \\ 368.2 & 383.8 & 584.5 \\ 236.5 & 260.8 & 374.0 \\ 131.7 & 123.0 & 210.5 \\ 80.1 & 106.0 & 117.6 \\ 9.8 & 23.6 & 20.4 \\ 84.8 & 197.0 & 167.6 \\ 4010 & 4569 & 4190 \\ & & \\ 16.0 & 17.8 & 16.0 \\ 2.7 & 3.1 & 2.6 \\ 11.3 & 12.3 & 11.3 \\ 6.1 & 8.0 & 7.3 \\ 10.1 & 9.2 & 8.4 \\ 2.7 & 3.5 & 3.2 \\ 10.8 & 11.5 & 10.6 \\ 2165 & 2396 & 94.1^{5} \\ 115.7^{4} & 102.4^{5} & \end{array}$

NM - natural matter; CP - crude protein; DE - digestible energy; GE - gross energy.

${ }^{1}$ Lignified protein: crude protein fraction of residues contained in acid detergent fiber.

2 Values obtained from Eggun (1970), Flores (1998), Villamide et al. (1998) and Ferreira et al. (2007).

${ }^{3} \mathrm{DE}(\mathrm{kcal} / \mathrm{kg} \mathrm{DM})=\mathrm{GE}(\mathrm{kcal} / \mathrm{kg} \mathrm{DM}) \times(84.77 \times 1.16 \%$ ADF on a dry matter basis $\left.)\right) / 100($ De Blas \& Mateos, 1998).

${ }^{4}$ Coefficient of digestibility according to Machado et al. (2007).

${ }^{5}$ Coefficient of digestibility according to Ferreira et al. (2007). 


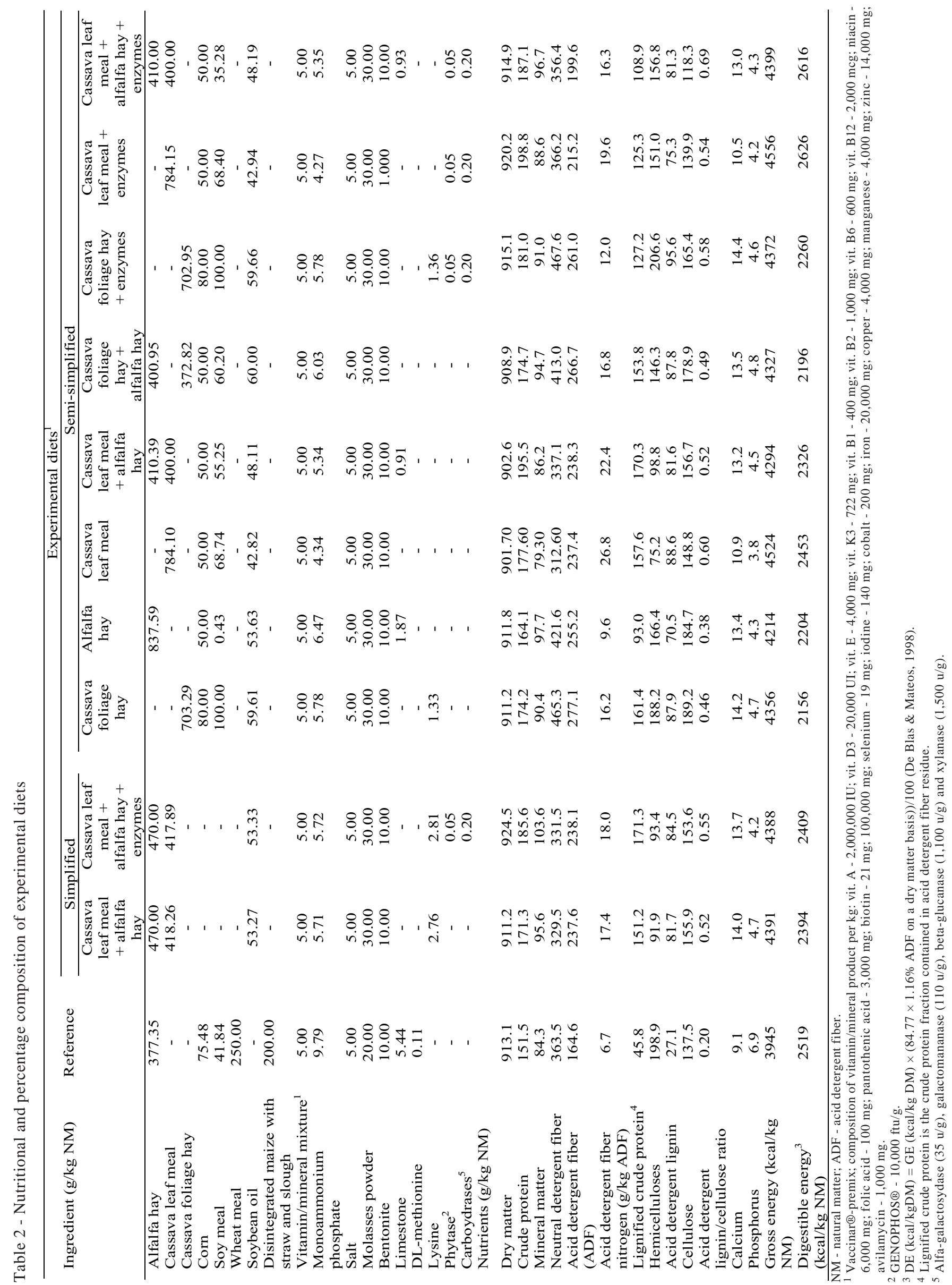


on the mix composed of hay from the upper third of the cassava foliage and alfalfa hay; simplified diet based on cassava leaf meal and alfalfa hay + carbohydrases and phytase enzymes; semi-simplified diet based on hay from the upper third of the cassava foliage + carbohydrases and phytase enzymes; semi-simplified diet based on cassava leaf meal + carbohydrases and phytase enzymes; semisimplified diet based on the mix composed of cassava leaf meal and alfalfa hay + carbohydrases and phytase enzymes (Table 2).

In the simplified diet based on cassava leaf meal and alfalfa hay with enzymes and semi-simplified diets based on hay from the upper third of the cassava foliage with enzymes, cassava leaf meal with enzymes and mix composed of cassava leaf meal and alfalfa hay with enzymes, phytase $\left(\right.$ GenoPhos ${ }^{\circledR}$ ),was added at the ratio of $50 \mathrm{~g} / \mathrm{t}$ (500 ftu/kg) and the enzyme complex (Endo Beta Power ${ }^{\circledR}$ ) was added in the proportion of $200 \mathrm{~g} / \mathrm{t}$, consisting of carbohydrases with alpha-galactosidase (35 u/g), galactomananase $(110 \mathrm{u} / \mathrm{g})$, beta-glucanase $(1,100 \mathrm{u} / \mathrm{g})$ and xylanase $(1,500 \mathrm{u} / \mathrm{g})$ activities. On the assay, the pelleted feed was offered ad libitum.

For each treatment, 51-day-old white New Zealand rabbits were used. The approbation by the animal ethics committee (CETEA/UFMG) is registered under number $171 / 08$. The methodology used was based on the European reference method for determination of in vivo digestibility for rabbits, proposed by the European Group of Animal Nutrition (Perez et al., 1995). The adaptation time was seven days, although all rabbits were already receiving the experimental diet from weaning, which was performed at 35 days of age. Intake and excreta of nutritional principles were determined on four consecutive days. On the first day of the collection period, before 9 am, the cages were cleaned, eliminating stool that could be attached to the base of the wire cage. Caecotrophy was not prevented at any time of the experiment.

The samples were collected and put in plastic bags, hermetically sealed and frozen at $-18^{\circ} \mathrm{C}$, for further laboratory analysis.

For the stool preparation, feces were pre-dried in forcedventilation oven circulating air at $55^{\circ} \mathrm{C}$, for 72 hours. The samples were ground to $1 \mathrm{~mm}$, and after dry matter, organic matter, crude protein and crude energy evaluations were analized according to the methods described by Silva \& Queiroz (2002) and Sindirações (2005). Gross energy was determined using calorimeter bomb (Parr adiabatic calorimeter). The analyses of neutral detergent fiber, acid detergent fiber, acid detergent lignin, acid detergent insoluble nitrogen, calcium and phosphorus were done in the ingredients and the experimental diets were performed according to the references cited in Van Soest et al. (1991).

The analyses were performed at the Laboratory of Animal Nutrition of the Department of Animal Science of EV-UFMG. For the diet calculation, data from the preanalysis of fiber mater and data from Villamide et al. (1998), Maertens et al. (2002) and Rostagno et al. (2005) were utilized.

The coefficient of apparent digestibility (DCa) of the dry matter, organic matter, crude protein and gross energy of the diets were calculated using the following equation:

DCa $(\mathrm{kg} / \mathrm{kg})=\underline{\text { Nutrient ingested }(\mathrm{kg})-\text { Nutrient feces }(\mathrm{kg})} \times 100$ Nutrient ingested $(\mathrm{kg})$

The methodology for determination of digestible energy and protein digestibility of fibrous ingredients followed the direct method, after determination of the digestibility of semi-simplified diets based on hay from the upper third of the cassava foliage, alfalfa hay and cassava leaf meal. In this methodology, the nutritional value of the feed tested (with high inclusion) is obtained by the difference between total nutrient content in the diet tested and the nutrient content in the feed pre-determined in the literature. The methodology employed by Fernandez-Carmona et al. (1998) was also used, in which $100 \%$ of digestibility was adopted for lysine; the digestible energy of $4.901 \mathrm{kcal} / \mathrm{kg}$ of natural matter and $858.0 \mathrm{~g} / \mathrm{kg}$ of natural matter for digestible protein (Rostagno et al., 2005) were considered. The values of digestible energy considered for soybean oil, dried molasses, corn and soybean meal were 8,$517 ; 2,780 ; 3,134$; and 3,182 kcal/kg of natural matter (Villamide et al., 1998), respectively. The digestible protein values considered for corn and soybean meal were 46.9 and $355.9 \mathrm{~g} / \mathrm{kg}$ of natural matter, obtained after chemical analysis and considering the digestibility reported by Villamide et al. (1998). The digestible protein of the molasses was not considered. Therefore:

Digestible energy $(\mathrm{DE})(\mathrm{kcal} / \mathrm{kg})$ of the diet $=\mathrm{DE}$ of the feed tested * $(\%)+\mathrm{DE}$ of soybean oil * $(\%)+\mathrm{DE}$ of corn * $(\%)+$ DE of soybean meal * $(\%)+$ DE of dry molasses * $(\%)$ + DE of lysine * $(\%)$.

Digestive protein (DP) (\%) of the diet $=$ DP of the feed tested * $(\%)+$ DP of corn * $(\%)+$ DP of soybean meal * $(\%)$ + DP of lysine * (\%).

The animals were distributed in a completely randomized design with 11 treatments and 8 replications, and the experimental unit consisted of a cage with one rabbit. The apparent digestibility values of different nutritional principles were submitted to analysis of variance, using the resources of the computer software SISVAR (Sistema de 
Análise de Variância, version 4.3) and means were compared by the Scott-Knott test, at 5\% probability. The treatments without enzymes and with the addition of exogenous enzymes were compared by the Scott-Knott test.

The statistic model used for the analyses of the variables was:

$$
\mathrm{Y} i j=\mu+\mathrm{R} i+\mathrm{e} i j
$$

in which: Yij = digestibility coeficient of the nutrients (gross energy, crude protein, dry matter and organic matter) and feed intake; $\mu=$ overall mean; $\mathrm{R} i=$ effect of the experimental diet $\mathrm{i}$; eij= random error associated to each $\mathrm{Y} i j$ observed.

\section{Results and Discussion}

The digestibility of nutritional principles was influenced $(\mathrm{P}<0.05)$ by the diet studied (Table 3$)$. The reference diet had the highest digestibility coefficients for all nutritional principles evaluated, especially due to the low content of acid detergent fiber, thus presenting a lower rate of passage, which aids digestion and absorption, with longer retention in the gastrointestinal tract. The simplified diets based on cassava leaf meal and alfalfa hay diets, cassava leaf meal and alfalfa hay with enzymes and semi-simplified diets based on cassava leaf meal, mix composed of cassava leaf meal and alfalfa hay, cassava leaf meal with enzymes and mix composed of cassava leaf meal and alfalfa hay with enzymes, containing cassava leaf meal, showed low protein digestibility. In the process of dehydration, the material was subjected to temperatures above $100{ }^{\circ} \mathrm{C}$. There was complexation of amino acids and carbohydrates, a phenomenon called the Maillard reaction. The semi-simplified diet based on cassava leaf meal with and without enzymes that contained high levels of inclusion of this ingredient had caramel aroma typical of the occurrence of this reaction.

Besides this, high concentration of protein was analyzed from the residue of acid detergent fiber (lignified protein) of these diets (Table 2). Quiñonez et al. (2007) noted the drop in the nutritional value of the carbohydrates when the cassava leaves were dried at $183^{\circ} \mathrm{C}$.

Rabbits are animals that, for their caecotrophic activity, increase the digestibility of protein, presenting higher values of digestibility when compared with other animals. Evaluating the digestibility of gross energy one can observe that the simplified diet based on cassava leaf meal and alfalfa hay and semi-simplified diet based on cassava leaf meal presented the worst results, followed by semi-simplified diets based on the mix composed of cassava leaf meal and alfalfa hay, cassava leaf meal, with and without enzymes and simplified diet based on cassava leaf meal and alfalfa hay with enzymes. Unlike what occurs with crude protein, rabbits have difficulty using gross energy of the diets with high levels of fiber, which is solved by a higher intake. Considering the dry matter intake, the simplified diet based on cassava leaf meal and alfalfa hay with enzymes and semisimplified diets based on cassava leaf meal, with and without enzymes presented $(\mathrm{P}<0.05)$ inferior results, suggesting that diets with high concentration of cassava leaf meal are also little palatable, leading to lower intake (Table 3). Throughout the experiment one could see that the animals did not accept well the diets with high levels of inclusion of this ingredient, especially the semi-simplified diets based on cassava leaf meal, with and without enzymes.

Another reason for low intake and digestibility of some diets was pointed out by Scapinello et al. (1999), who noticed that hay from the upper third of the cassava foliage

Table 3 - Apparent digestibility coefficients and average consumption of the experimental diets

\begin{tabular}{|c|c|c|c|c|c|}
\hline \multirow[b]{2}{*}{ Diet } & \multicolumn{4}{|c|}{ Digestibility coefficient } & \multirow{2}{*}{$\begin{array}{c}\text { Average } \\
\text { consumption } \\
\text { (g/day) }\end{array}$} \\
\hline & $\begin{array}{c}\text { Crude protein } \\
(\mathrm{kg} / \mathrm{kg})\end{array}$ & $\begin{array}{c}\text { Gross energy } \\
(\mathrm{kg} / \mathrm{kg})\end{array}$ & $\begin{array}{l}\text { Dry matter } \\
(\mathrm{kg} / \mathrm{kg})\end{array}$ & $\begin{array}{c}\text { Organic matter } \\
(\mathrm{kg} / \mathrm{kg})\end{array}$ & \\
\hline Reference & $0.7834 \mathrm{a}$ & $0.6638 \mathrm{a}$ & $0.6557 a$ & $0.6725 a$ & $99.93 a$ \\
\hline \multicolumn{6}{|l|}{ Simplified } \\
\hline Cassava leaf meal + alfalfa meal & $0.5801 \mathrm{e}$ & $0.5086 \mathrm{~d}$ & $0.5391 \mathrm{~d}$ & $0.5413 d$ & $91.38 \mathrm{a}$ \\
\hline Cassava leaf meal + alfalfa meal with enzymes & $0.6126 \mathrm{~d}$ & $0.5454 c$ & $0.5735 c$ & $0.5851 b$ & $84.65 b$ \\
\hline \multicolumn{6}{|l|}{ Semi-simplified } \\
\hline Foliage cassava hay & $0.6810 c$ & $0.5345 c$ & $0.5423 \mathrm{~d}$ & $0.5428 d$ & $94.73 a$ \\
\hline Alfalfa hay & $0.7223 b$ & $0.5667 \mathrm{~b}$ & $0.5694 \mathrm{c}$ & $0.5669 c$ & $99.78 a$ \\
\hline Cassava leaf meal & $0.4548 f$ & $0.4884 \mathrm{~d}$ & $0.5307 d$ & $0.5275 d$ & $78.15 b$ \\
\hline Cassava leaf meal + alfalfa hay & $0.6279 d$ & $0.5403 c$ & $0.5729 c$ & $0.5698 c$ & $98.50 \mathrm{a}$ \\
\hline Foliage cassava hay + alfalfa hay & $0.7289 b$ & $0.5689 b$ & $0.5752 \mathrm{c}$ & $0.5682 \mathrm{c}$ & $94.38 \mathrm{a}$ \\
\hline Foliage cassava hay + enzymes & $0.7108 b$ & $0.5582 b$ & $0.5640 \mathrm{c}$ & $0.5643 c$ & $92.30 \mathrm{a}$ \\
\hline Cassava leaf meal + enzymes & $0.5690 \mathrm{e}$ & $0.5480 \mathrm{c}$ & $0.5937 b$ & $0.5904 b$ & $76.05 b$ \\
\hline Cassava leaf meal + alfalfa hay + enzymes & $0.6363 d$ & $0.5685 b$ & $0.5941 b$ & $0.5930 b$ & $91.70 \mathrm{a}$ \\
\hline Variation coefficient (\%) & 4.20 & 4.58 & 4.00 & 4.05 & 14.03 \\
\hline
\end{tabular}

Means followed by different letters differ by the Scott-Knott test at 5.0\% probability. 
has free and condensed tannins, and these substances also affect nutrient digestibility. These substances can form stable structures with protein, holding them at the digestive tract, reducing their digestibility, and inhibiting digestive enzymes (Ferreira, 1994; McDougall et al., 1996).

Machado et al. (2007) evaluated simplified diets for rabbits and found, for the simplified diet based on alfalfa hay, $0.5238,0.5299,0.6730$ and 0.5432 for the coefficient of digestibility of dry matter, organic matter, crude protein, and gross energy, respectively, and these values were intermediate to those found in this experiment. In the study previously mentioned, from the simplified diet based on alfalfa hay, the authors found values of $0.3304,0.3332$, 0.4958 and 0.3167 for the digestibility of dry matter, organic matter, crude protein, and gross energy, which were inferior to all the values observed in this experiment.

The values found in the present study are in consonance with the values observed by Ferreira et al. (2007), who found digestibility coefficients in the order of $0.537 ; 0.504 ; 0.681$ and $0.537 \mathrm{~kg} / \mathrm{kg}$ for dry matter, organic matter, crude protein and gross energy respectively, for the simplified diet based on alfalfa hay and values of 0.476 ; $0.464 ; 0.520$; and 0.490 for the respective nutritional principles of the simplified diet based on hay from the upper third of the cassava foliage.

Fernandez-Carmona et al. (1998), evaluated simplified diets based on alfalfa hay, and found values of digestibility coefficients for dry matter, organic matter and crude protein in the order of $0.530 ; 0.545$ and $0.645 \mathrm{~kg} / \mathrm{kg}$, respectively, for a diet of $960 \mathrm{~g}$ of alfalfa hay per kg of natural matter. For a similar diet with inclusion of $89.0 \mathrm{~g}$ of oil per $\mathrm{kg}$ of natural matter, values of $0.540 ; 0.550$ and $0.660 \mathrm{~kg} / \mathrm{kg}$ were found for digestibility of the respective nutritional principles. These values are close to the ones obtained in this experiment for the semi-simplified diet based on alfalfa hay. Faria et al (2008) observed coefficients of 0.500, 0.733 and $0.506 \mathrm{~kg} / \mathrm{kg}$ for dry matter, crude protein and gross energy for simplified diet based on alfalfa hay and 0.296, 0.469 and $0.245 \mathrm{~kg} / \mathrm{kg}$ for the respective nutritional principles of the simplified diet based on hay from the upper third of the cassava foliage. The author reinforced the hypothesis of low digestibility of the last diet, due to the presence of tannins, as proposed by Scapinello et al. (1999).

On can perceive that, overall, the simplified diets used in the essays mentioned presented lower values of digestibility coefficients, when compared with semisimplified diets, with the same fiber sources, used in this experiment, reinforcing the idea of improving the digestive process when adding minimum levels of starch and protein of acknowledged nutritional quality. This fact can be explained by the higher digestibility of starch and protein sources, besides the improvement of the whole digestive process, especially in the caecal level, as indicated by Machado et al. (2007).

As to the effect of endogenous enzymes (carbohydrases and phytase) from the comparison between diets without enzymes and with enzymes, only between semi-simplified based on the mix of cassava leaf meal and alfalfa hay and semi-simplified based on the mix of cassava leaf meal and alfalfa hay with enzymes were no improvements in the digestibility observed. The other enzyme inclusions promoted better results in the digestibility of the nutrition principles. In the general comparison between treatments without enzymes and their respective treatments with enzymes, it can be verified that the inclusion promoted better nutrient digestibility (Table 4). It is clear that the exogenous enzymes made the digestibility of all nutritional principles better.

The observed results are in agreement with Gutierrez et al. (2000), who reported improvement $(\mathrm{P}<0.05)$ in the digestibility of crude protein when the phytase enzyme was added in diets for rabbits. In that study, the authors observed improvement of $7 \%$, close to the $8 \%$ observed here in the overall comparison. Falcão \& Cunha et al. (2008) noted improvements in the digestibility of the cell wall when the galactosydase enzyme was added to the diets. Thus, the ability of the enzymes to improve the use of the nutritional principles in diets for rabbits became clear.

The reference diet and the semi-simplified diets based on mix of hay from the upper third of the cassava foliage and alfalfa hay, cassava leaf meal whit enzymes and mix of cassava leaf meal and alfalfa hay with enzymes presented

Table 4 - Apparent digestibility coefficient of diets with high inclusion of fiber in relation to the presence or absence of exogenous enzymes

\begin{tabular}{lcccc}
\hline Diet & \multicolumn{4}{c}{ Digestibility coefficients } \\
\cline { 2 - 5 } & $\mathrm{CP}(\mathrm{kg} / \mathrm{kg})$ & $\mathrm{GE}(\mathrm{kg} / \mathrm{kg})$ & $\mathrm{DM}(\mathrm{kg} / \mathrm{kg})$ & $\mathrm{OM}(\mathrm{kg} / \mathrm{kg})$ \\
\hline Diet without enzymes & $0.5871 \mathrm{~b}$ & $0.5184 \mathrm{~b}$ & $0.5469 \mathrm{~b}$ & $0.5460 \mathrm{~b}$ \\
Diets with enzymes & $0.6341 \mathrm{a}$ & $0.5548 \mathrm{a}$ & $0.5805 \mathrm{a}$ & $0.5826 \mathrm{a}$ \\
Variation coefficient (\%) & 12.28 & 5.73 & 4.96 & 4.91 \\
\hline
\end{tabular}

CP - crude protein; GE - gross energy; DM - dry matter; OM - organic matter.

Means followed by different letters, in same colum, differ by the Scott-Knott test at $5.0 \%$ probability. 
a level of digestible energy close to the one proposed by De Blas \& Mateos (1998), which is $2500 \mathrm{kcal} / \mathrm{kg}$ of natural matter (Table 5). However, all the other diets showed levels greater than $2.200 \mathrm{kcal} / \mathrm{kg}$ dry matter, in which the animal regulates its intake as a function of energy density (Ferreira \& Pereira, 2003; De Blas et al., 2002).

It can be noted that the semi-simplified diet based on cassava leaf meal and simplified diet based on cassava leaf meal and alfalfa hay had lower levels of digestible protein than recommended by De Blas \& Mateos (1998), which is 102 to $113 \mathrm{~g} / \mathrm{kg}$ of natural matter and the other diets showed slightly higher levels. Ferreira \& Pereira (2003) found that the ratio between digestible energy and digestible protein, per kg, should be between 22 and $25 \mathrm{kcal}$. Thus the semisimplified diets based on hay from the upper third of the cassava foliage, alfalfa hay, mix composed of cassava leaf meal and alfalfa hay, cassava leaf meal with enzymes, mix composed of hay from the upper third of the cassava foliage and alfalfa hay and simplified diet based on cassava leaf meal and alfalfa hay with enzymes presented relations below the proposal, which suggests a lack of energy in relation to the protein. The opposite is observed in the semisimplified diet based on cassava leaf meal, which suggests a lack of protein in relation to energy.

All diets used in this experiment had higher energy content than those used by Machado et al. (2007) who obtained unsatisfactory results with simplified diets. Fernandez-Carmona et al. (1998) found values of 2143.5 and $2418.7 \mathrm{kcal} / \mathrm{kg}$ of natural matter for the diets with 960.0 and $881.0 \mathrm{~g}$ of alfalfa hay per kg of natural matter, respectively, and the first value was inferior to all the diets used in this experiment. Gidenne (2000) proposes energy levels of 2250 to $2350 \mathrm{kcal} \mathrm{DE} / \mathrm{kg}$ of natural matter until 45 days and 2350 to 2450 from the 46 day until slaughter. Most diets dealt with in this study met these requirements.
The same author proposes digestible protein requirement superior to 115.0 per kg of natural matter until 45 days and 110.0 - 115, from the 46 day until slaughter. Thus, except for the diets simplified based on cassava leaf meal and alfalfa hay and semi-simplified based on cassava leaf meal, all the others met the requirements of digestible energy. Still, by the recommendation of Gidenne (2000) for the quantity of fiber offered to the animals, it can be seen that the reference diet contains acid detergent fiber, lignin and acid detergent lignin/cellulose ratio inferior to the one proposed (Table 2), although balanced according to the recommendations of De Blas \& Matheus (1998). Another recommendation is made as to the level of acid detergent lignin, which can be of 50 to $70 \mathrm{~g} / \mathrm{kg}$ of natural matter, range in which the diets used in this study are not comprised (Table 2). Simplified diets provide excess of fiber components, which hampers the balance of some feed fractions. Gidenne (2000) also mentions that the level of hemicelluloses must be higher than $129 \mathrm{~g} / \mathrm{kg}$ of natural matter for rabbits until 45 days and $100 \mathrm{~g} / \mathrm{kg}$ of natural matter from 46 days till slaughter. Thus, some of the diets used here did not have this amount of hemicelluloses.

In relation to the nutritional value of the fiber sources, the hay from the upper third of the cassava foliage presented $1822.7 \mathrm{kcal}$ of digestible energy and $122.6 \mathrm{~g}$ of digestible protein per kg of dry matter; the alfalfa hay presented $2232.5 \mathrm{kcal}$ of digestible energy and $155.4 \mathrm{~g}$ of digestible protein per kg of dry matter and cassava leaf meal presented $1888.9 \mathrm{kcal}$ of digestible energy and $73.6 \mathrm{~g}$ of digestible protein per kg of dry matter. The cassava leaf meal presented low level of digestible protein, due to the elevation of the temperature during the processing in the adapted tea machine (Ferreira et al., 2011). This situation fosters the union of the amino acids and reduced carbohydrates, turning them into an insoluble complex, which is called "the Maillard reaction".

Table 5 - Nutritional levels of digestible energy and digestive protein and energy/protein ratio of the experimental diets

\begin{tabular}{lccc}
\hline Diet & $\begin{array}{c}\text { Digestible energy } \\
(\mathrm{kcal} / \mathrm{kg})\end{array}$ & $\begin{array}{c}\text { Digestible protein } \\
(\mathrm{g} / \mathrm{kg})\end{array}$ & $\begin{array}{c}\text { Digestible energy/digestible } \\
\text { protein }\end{array}$ \\
\hline refatio
\end{tabular}


Scapinello et al. (1999) evaluated the nutritional value of hay from the upper third of the cassava foliage, harvested at 15 months of age, and found values of $1901.8 \mathrm{kcal} / \mathrm{kg}$ dry matter and $89.2 \mathrm{~g}$ of digestible protein per kg of dry matter; the energy value was close to that observed in this study.

\section{Conclusions}

Overall, semi-simplified diets promoted intermediate digestibility coefficients between traditional diets and simplified diets. Diets with high inclusion of cassava leaf meal, above $40 \%$, presented lower digestibility values for the nutritional principles when compared with traditional ones. The exogenous enzymes (phytase and carbohydrases) provided significative improvements in the digestibility of the nutritional principles of the simplified and semi-simplified diets.

\section{References}

BEDFORD, M.R. Exogenous enzymes in monogastric nutrition: their current value and future benefits. Animal Feed Science and Technology, v.86, p.1-13, 2000.

BERTECHINI, A.G. Nutrição de monogástricos. Lavras: UFLA, 2006. 301p.

CARABAÑO, R.M.; FRAGA, M.J.; SANTOMÁ, G. et al. Effect of diet on composition of cecal contents and on excretion and composition of soft and hard feces of rabbits. Journal ofAnimal Science, v.66, n.4, p.901-910, 1988.

CARABAÑO, R.; PIQUER, J. The digestive system of the rabbit. In: DE BLAS, J.C.; WISEMAN, J. The nutrition of the rabbit. Cambridge: CAB International, 1998. p.1-16.

CHEEKE, P.R.; GROBNER, M.A.; PATTON, N.M. Fiber digestion and utilization in rabbits. Journal Applied Rabbit Research, v.9, p.25-30, 1986.

DARI, R.L. A utilização de fitase na alimentação de aves. In: CONFERÊNCIA APINCO DE CIÊNCIA E TECNOLOGIA AVÍCOLAS, 2004, Santos. Anais... Castelo - Campinas: FACTA, 2004. p.128-143.

DE BLAS, J.C.; MATEOS, G.G. Feed formulation. In: DE BLAS, J.C.; WISEMAN, J. (Eds.) The nutrition of the rabbit. Cambridge: CAB International, 1998. p.241-253.

DE BLAS, J.C.; GARCIA J.; CARABAÑO R.M. Avances em nutrición de conejos. In: SIMPOSIUM DE CUNICULTURA, 27., 2002, Réus. Anais... Réus, 2002. p.83-91.

EGGUM, B.O. The protein quality of cassava leaves. British Journal of Nutrition, v.24, p.761-768, 1970.

FALCÃO E CUNHA, L.; SABINO, I.; CASTRO-SOLLA, L. et al. Improving the nutritive value of lupin seed for growing rabbits: galactosidade enzymes vs. washing. In: WORLD RABBIT CONGRESS, 9., 2008, Verona. Proceedings... Verona, 2008. p.661-666.

FARIA, H.G.; FERREIRA, W.M.; SCAPINELLO, C. et al. Efeito da utilização de dietas simplificadas, à base de forragem, sobre a digestibilidade e o desempenho de coelhos Nova Zelândia. Revista Brasileira de Zootecnia, v.37, n.10, p.1797-1801, 2008.

FERNANDEZ-CARMONA, J.; BERNAT, F.; CERVERA, C. et al. High lucerne diets for growing rabbits. World Rabbit Science, v.6, n.2, p.237-240, 1998
FERREIRA, M.; MACHADO, L.C.; FERREIRA, W.M. et al. Parte aérea de diferentes cultivares de mandioca como fonte de fibra para utilização na alimentação animal. Revista Raízes e Amidos Tropicais, v.7, n.1, p.1-11, 2011.

FERREIRA, W.M. Os componentes da parede celular vegetal na nutrição de não ruminantes. In: SIMPÓSIO INTERNACIONAL DE PRODUÇÃO DE NÃO RUMINANTES, 31., 1994. Maringá. Anais.... Maringá: SBZ, 1994. p.85-113.

FERREIRA, W.M.; PEREIRA, R.A.N. Avanços na nutrição de coelhos Avaliação energética e protéica dos alimentos e necessidades nutricionais. In: Nutrição animal: Tópicos avançados. Itapetinga: Departamento de Tecnologia Rural e Animal - UESB, 2003. p.15-34. FERREIRA, W.M.; HERRERA, A.D.P.N.; SCAPINELLO, C. et al. Digestibilidade aparente dos nutrientes de dietas simplificadas baseadas em forragens para coelhos em crescimento. Arquivo Brasileiro de Medicina Veterinária e Zootecnia, v.59, n.2, p.451-458, 2007.

FLORES, C.I.O. Caracterização química e avaliação da biodisponibilidade de $\boldsymbol{\beta}$-caroteno e da proteína da folha de mandioca (Manihot esculenta Crantz) desidratada. 1998. 160f. Tese (Doutorado em Ciência dos Alimentos) - Faculdade de Ciências Farmacêuticas, Universidade de São Paulo, São Paulo.

GIDENNE, T. Recent advances in rabbit nutrition: emphasis on fibre requirements, a review. World Rabbit Science, v.8, n.1, p.23-32, 2000.

GUTIÉRREZ, I.; GARCIA, J.; CARABAÑO, R. et al. Effect of exogenous phytase on phosphorus and nitrogen digestibility on growing-finishing rabbits. In: WORLD RABBIT CONGRESS, 7., 2000, Valencia. Proceedings... Valencia, 2000. p.277-281.

MACHADO, L.C.; FERREIRA, W.M.; FARIA, H.G. et al. Avaliação da digestibilidade aparente de dietas simplificadas com base em forragens para coelhas em reprodução. Veterinária e Zootecnia, v.14, n.1, p.81-90, 2007.

McDOUGALL, G.; MORRISON, I.M.; STEWART, D. et al. Plant cell walls as dietary fibre: range, structure, processing and function. Journal of the Science of Food and Agriculture, v.70, p.133-150, 1996.

MAERTENS, L.; PEREZ, J.M.; VILLAMIDE, M. et al. Nutritive value of raw materials for rabbits: Egran tables 2002. World Rabbit Science, v.10, n.4, p.157-166, 2002.

NAGASHIRO, C. Enzimas na nutrição de aves. In: CONFERÊNCIA APINCO DE CIÊNCIA E TECNOLOGIA AVÍCOLAS, 2007, Santos. Anais... Castelo - Campinas: FACTA, 2007. p.309-327.

PEREZ, J.M.; CERVERA, C.; FALCÃO E CUNHA L. et al. European ring-test on in vivo determination of digestibility in rabbits: reproducibility of a reference method compared with individual laboratory procedures. World Rabbit Science, v.3, n.4, p.171-178, 1995.

QUIÑÓNEZ,. R.; GONZÁLEZ, C; POLANCO, D. et al. Evaluación de diferentes tipos de desidratación de raiz y follaje de yuca amarga (Manihot esculenta) sobre su composición química. Zootecnia Tropical, v.25, n.1, p.43-49, 2007.

ROSTAGNO, H.S. Tabelas brasileiras para aves e suínos: composição de alimentos e exigências nutricionais. 2.ed. Viçosa, MG: UFV, Departamento de Zootecnia, 2005. 186p.

SANTOS, E.A.; LUI, J.F.; SCAPINELLO, C. Efeito dos níveis de fibra em detergente ácido sobre os coeficientes de digestibilidade das dietas e desempenho de coelhos em crescimento. Acta Scientiarum Animal Sciences, v.26, n.1, p.79-86, 2004.

SCAPINELLO, C.; FALCO, J.E.; FURLAN, A.C. et al. Valor nutritivo do feno da rama de mandioca (Manihot esculenta, Crantz) para coelhos em crescimento. Revista Brasileira de Zootecnia, v.28, n.5, p.1063-1067, 1999.

SILVA, D.J.; QUEIROZ, A.C. Análise de alimentos: métodos químicos e biológicos. 3.ed. Viçosa, MG: UFV, 2002. 235p.

SINDICATO NACIONAL DA INDÚSTRIA DE ALIMENTAÇÃO ANIMAL - SINDIRAÇÕES. Compêndio brasileiro de alimentação 
animal. Campinas: Sindirações; ANFAR, CBNA e Ministério da Agricultura, 2005. 308p.

VAN SOEST, P.J.; ROBERTSON, J.B.; LEWIS, B.A. Methods for dietary fiber, neutral detergent fiber, and nonstarch polysaccharides in relation to animal nutrition. In: Symposium: carbohydrate methodology, metabolism, and nutritional implications in dairy cattle. Journal of Dairy Science, v.74, p.3583-3597, 1991.

VILLAMIDE, M.J.; MAERTENS, C.; DE BLAS, C. et al. Feed evaluation. In: DE BLAS, C., WISEMAN, J. The nutrition of the rabbit. Cambridge: CAB International, 1998. p.89-102. 